The Cryosphere Discuss., doi:10.5194/tc-2015-235, 2016

Manuscript under review for journal The Cryosphere

Published: 29 February 2016

(c) Author(s) 2016. CC-BY 3.0 License.

\title{
A Close Observation to a Typical Continental Valley Glacier Surge in Northeastern Pamir
}

\author{
Xin YAO ${ }^{1}$, Fuchu DAI ${ }^{2}$, Iqbl. JAVED ${ }^{3}$, Lingjing. LI ${ }^{1}$, Zhongsheng WANG ${ }^{1}$, Sheng LING ${ }^{1}$, Zhengkai ZHOU $^{1}$ \\ 1) Key Laboratory of Neotectonic Movement and Geohazards, Ministry of Land and Resource, Institute of \\ Geomechanics, Chinese Academy of Geological Sciences, Beijing, 100086 \\ 2) Beijing University of Technology, Beijing, 100124 \\ 3) Department of Earth Sciences, Abbottabad University of Science and Technology, KPK, Pakistan, 22010 \\ Correspondence to: X. YAO (yaoxinphd@163.com)
}

\section{Key Points:}

$>$ A close expedition and multi-temporal RS interpretation discovered a rare continental glacier surge.

$>\quad$ It has significant observation difference between quiescent phase and surging phase.

$>$ Relatively higher ice choking uplift and large chaotic crevasses area extent, but having small integral movement distance with low velocity are its characteristics as compared with oceanic glacier surging.

$>$ Stagnant downstream tongue and thick superglacial moraine mostly contributed to this type surge's features.

\begin{abstract}
:
In May 2015, it is reported that "a glacier slid $20 \mathrm{~km}$ long, accompanying with disappearance of $\sim 10 \mathrm{~km}^{2}$ grasslands on the north slope of Mt Jiubie, Kongur Mountain, northeastern Pamir, China". Based on expedition and multi-temporal RS image interpretation, this paper confirms that it was a rare continental valley glacier surge occurred in the tributaries of Kalayayilake Glacier, and find: (1) It has significant phenomena difference between quiescent and surging phase, including distorted medial moraine ridge, extruding-bulging ice masses, disappeared superglacial lakes etc; (2) Compared with the oceanic glacier surge, its characteristics are higher ice choking uplift and large chaotic crevasses area extent, but having relatively small integral movement distance with low velocity; (3) Environmental factors of large glacier coefficient, long tongue, low altitude, especially the stagnant downstream tongue and thick superglacial moraine, contribute to continental glacier surge's features, and the long-term temperature rise and rainfall enhancement in study area seem to be consistent with the occurrence of this surge; (4) This surge brings out severe strength reduction of glacier, rapid ablation of ice, congestion in the subglacial passageway, and accumulation of englacial water, which together have being bred the risk of terminus advance suddenly to result in flooding and debris flow.
\end{abstract}

Keywords: Glacier surging; Continental glacier; Northeastern Pamir; Glacier disasters; Geo-hazard

\section{Introduction}

Glacier surge generally occurs when the ice tongue moves at a velocity several times the normal velocity for days or years (Meier and Post, 1969), accompanying with many extreme phenomena. Surge is the "earthquake" in the glacier regime and it has a great significance for complete and deep understanding of glaciers. The moisture-sufficient oceanic glacier surges have already been reported extensively, such as Black Rapids Glacier and Variegated Glacier in Alaska, North America (Kamb et al., 1985); Trapridge Glacier and others in the St. Elias Mountains, Yukon Territory, Canada (Frappe and Clarke, 2007; Clarke et al., 1986); polar glaciers In Iceland (Jónsson et al., 2014); Midui Glacier and Zelongnong Glacier in eastern Himalayan (Zhang, 1983); dozens of glaciers in Karakorum (Shi and Zhang, 1978; Yao et al., 2004; 
The Cryosphere Discuss., doi:10.5194/tc-2015-235, 2016

Manuscript under review for journal The Cryosphere

Published: 29 February 2016

(c) Author(s) 2016. CC-BY 3.0 License.

Kotlyakov et al., 2008; Copland et al., 2011; Quincey et al., 2011, 2015); transitional glaciers from the oceanic type to semi-continental type in Shaksgam River (Mustagh river) areas; north slope of Karakorum Mountains (Shangguan et al., 2005; Liu and Wang, 2009).

While in the cold and arid inlands (such as northern margin of Tibet Plateau) and high mountains of central Asia (Tian Shan), continental glacier surges have been hardly observed. There were only some cases about relics or suspected phenomena reported, and lacking of detail describes and expeditions (Li et al., 2013; Niu et al., 2011; Guo et al., 2012; Holzer et al, 2015), which made the less understand for this type surge.

In May 2015, herdsmen, residing near Kelayayilake Glacier, Xinjiang province, China (Fig. 1), stated that the large-area grasslands disappeared and replaced by numerous "fierce-looking and saber-rattling" black ice masses, which was reported by incomplete realization and extensively informed to the public about "the glacier slid $20 \mathrm{~km}$ and destroyed $\sim 10 \mathrm{~km}^{2}$ grasslands". This paper confirms that it was a very rare continental glacier surge, and presents a close and dynamic observation based on field investigation and interpretation of multi-temporal RS images, gains some new finds.

56

\section{Glacier environment}

\subsection{Geological setting}

The Kelayayilake Glacier is located on the north slope of Mt. Jiubie, Kongur Mountain, northeastern Pamir, with a peak $7649 \mathrm{~m}$ above sea level (a.s.1.) and valley-mouth of $2485 \mathrm{~m}$ a.s.1.. In , the southeast side, about $50 \mathrm{~km}$ away, is the famous Muztag Ata (7546 m a.s.1.), and in the northwestern is the $5753 \mathrm{~m}$ a.s.1. Kungai Mountains. These high mountains tectonically resulted from the combined action of thrusting uplift of north Pamir fault as well as the extensional orogenesis of Kongur normal fault at the south side (Robinson et al., 2004). The Gez active fault, passing through Kelayayilake glacier, is NWW-trending, $190 \mathrm{~km}$ long and dextral with inclination direction of $230^{\circ}$ and inclination angle of $40^{\circ}-76^{\circ}$ (Fig. $2 \mathrm{~A}$ ), and its active triggered an $M s$ 6.4 earthquake on Nov. 15, 1959. The lithology is mainly Lower Proterozoic (Pt1) hypometamorphic schist. Between Kungai Mountain and Kongur Mountain, the SW-NE flowing Gez River crosscuts northeastern margin of Pamir Plateau, and into which Kelayayilake Glacier drainage converges (Fig. 1).

\subsection{Hydroclimatology condition}

The study area is an extreme continental glacier zone with very low temperature, and its precipitation mainly comes from the mid-latitude westerly circulation and local circulation (Shi, 2000). The nearby Gez River valley has annual average temperature lower than $5{ }^{\circ} \mathrm{C}$, whereas the temperatures in mountainous areas range from -27.2 to $32.7^{\circ} \mathrm{C}$. The annual precipitation ranges from 60 to $120 \mathrm{~mm}$ (Mao et al., 2006; Shi et al., 2006). Due to the large altitude difference, topographical complexity and climate difference, the spatio-temporal distribution of precipitation is non-uniform. The precipitations increases with the increase in elevations, and the annual precipitations near the equilibrium lines ( $4200 \mathrm{~m}$ a.s.1.) is $477-679 \mathrm{~mm}$ ( $\mathrm{Su}$, et al., 1989). At regional scale, the annual temperatures and precipitations in south Xinjiang and northeastern Pamir have been increasing since 1960s. The watershed is getting significantly wetter and warmer by late 1990s, and the river runoff volumes in recent 47 years have been rising by 3.0\%/10years (Mao et al., 2006). The average annual precipitations in southern Xinjiang increased by $32 \%$ from 1956-1986 to 1987-2000. The average temperatures in Gez River watershed in recent 40 years increased by $0.23{ }^{\circ} \mathrm{C} / 10$ years (Xue, et al., 2003). 
The Cryosphere Discuss., doi:10.5194/tc-2015-235, 2016

Manuscript under review for journal The Cryosphere

Published: 29 February 2016

(c) Author(s) 2016. CC-BY 3.0 License.

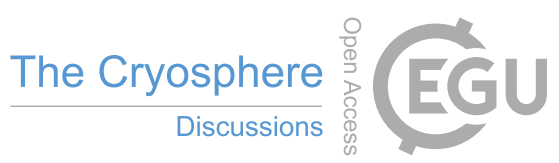

(c) $($ i)
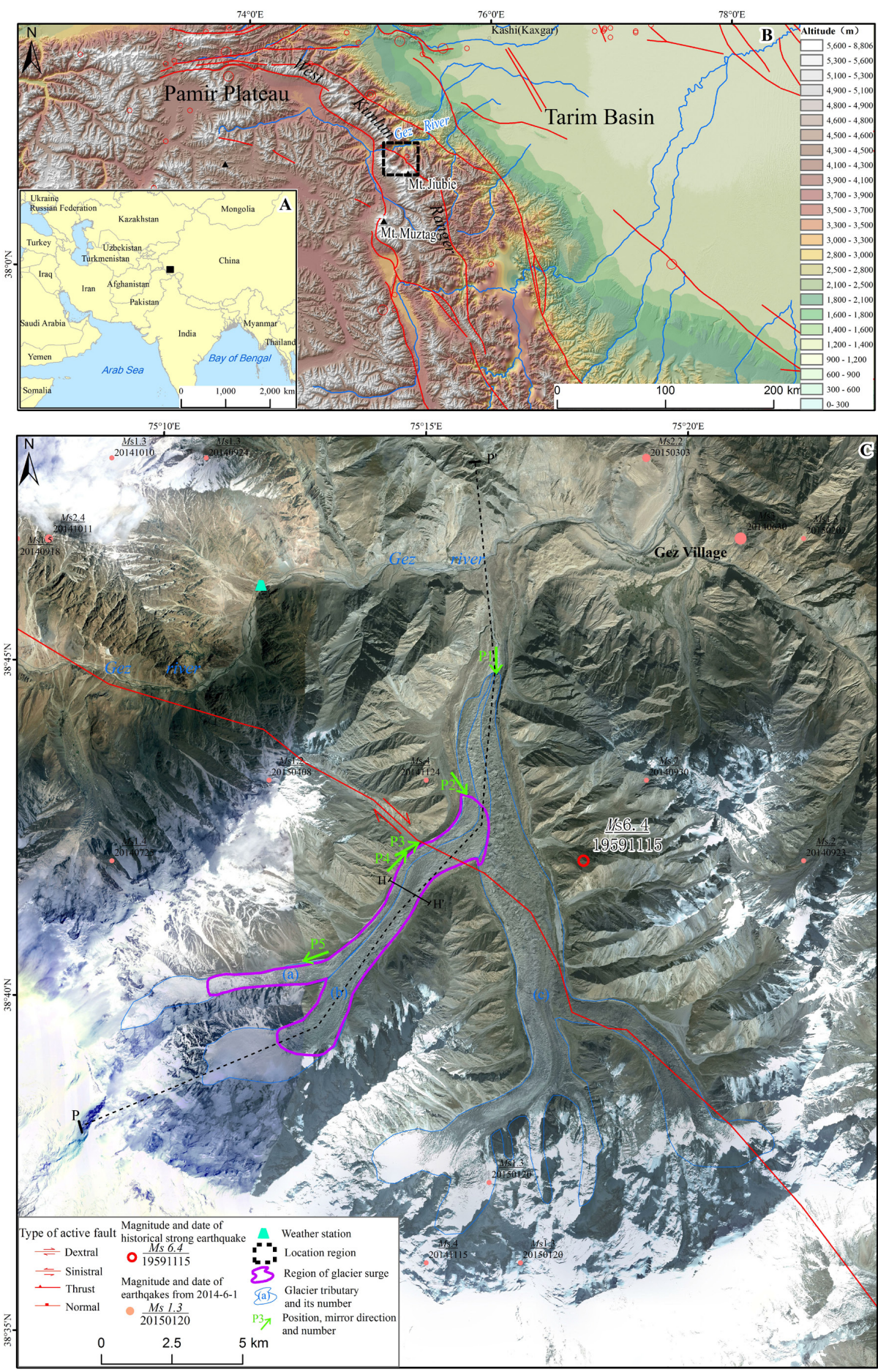

Fig. 1 Location, topographical characteristics of glacier, region of two surging tributaries and profiles positions, back ground is $1 \mathrm{~m}$ resolution remote sensing image 
The Cryosphere Discuss., doi:10.5194/tc-2015-235, 2016

Manuscript under review for journal The Cryosphere

Published: 29 February 2016

(c) Author(s) 2016. CC-BY 3.0 License.
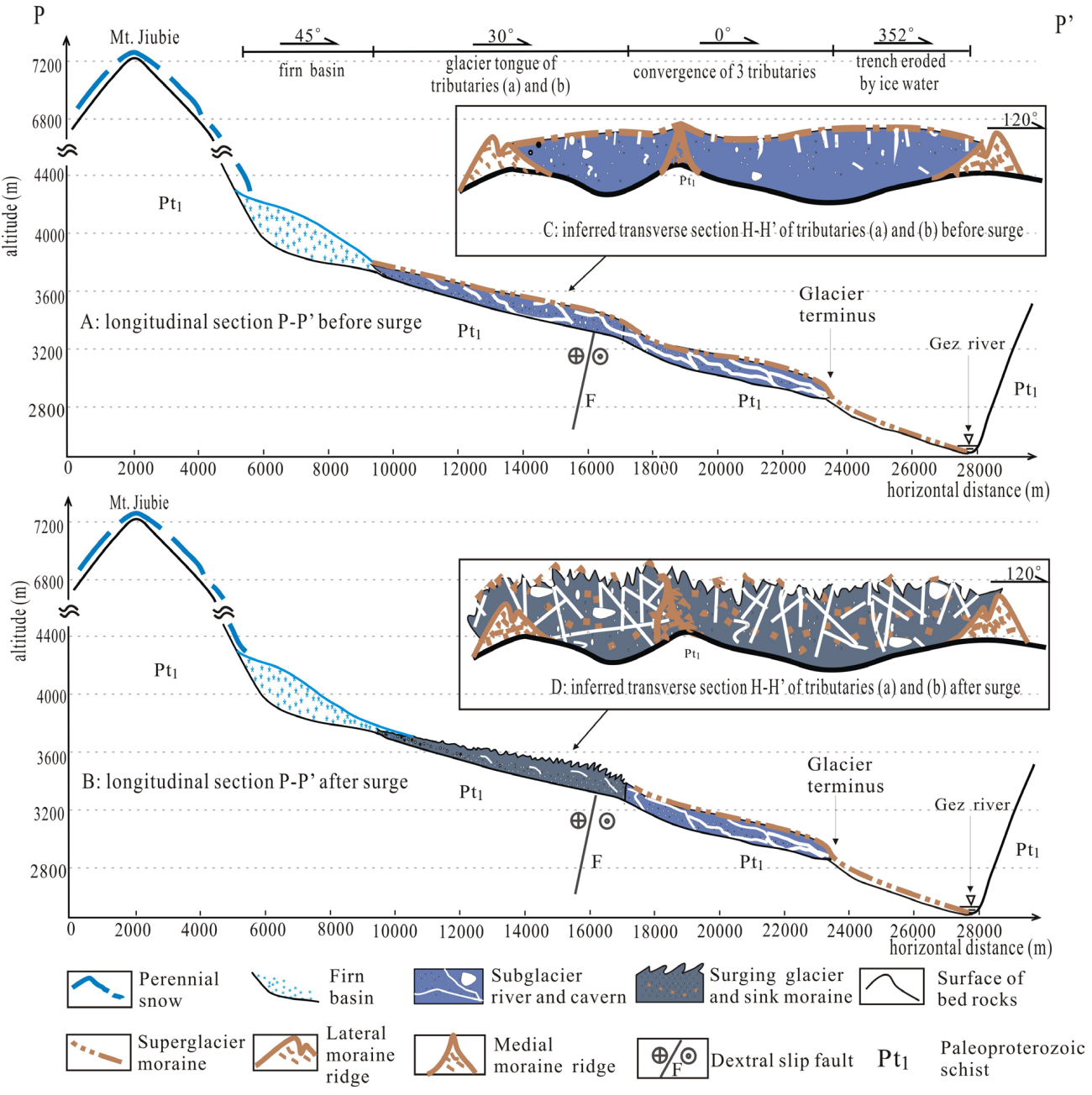

Fig. 2 Sections of Kelayayilake Glacier before and after surge

\subsection{Glacier parameters}

Kongur Mountain together with Muztag Ata and Kungai Mountain are the barriers between Pamir Plateau and Tarim Basin which effectively block the moist circulation from the west and guarantee the favorable condition for development and growth of modern glaciers in this region. The modern glaciers are radial and feather-like glaciers distributed around Alps and ridges, mostly at an elevation of $4000 \mathrm{~m}$ a.s.l. and above. The general snow lines are at altitude of 4200-5200 m a.s.1.. As typical continental glaciers, their velocity and melting are relatively low.

The Kelayayilake Glacier, $20.3 \mathrm{~km}$ long and covering $128.15 \mathrm{~km}^{2}$ with an ablation area of $47.1 \mathrm{~km}^{2}$, is the largest modern glacier on the north slope of Kongur Mountain. It has a glacier coefficient RAA (Ratio of Accumulation area to Ablation area) of 0.63 , with an equilibrium line elevation $\sim 4200 \mathrm{~m}$ a.s.l., glacier terminus of $2780 \mathrm{~m}$ a.s.l. and having upper limit of firn basin is up to $5300 \mathrm{~m}$ a.s.l. The glacier consists of three major tributaries (the west, the middle and the east marked as (a), (b) and (c) respectively), and due to 
The Cryosphere Discuss., doi:10.5194/tc-2015-235, 2016

Manuscript under review for journal The Cryosphere

Published: 29 February 2016

(c) Author(s) 2016. CC-BY 3.0 License.

the slow movement, two neat Medial Moraine Ridges (MMR) are formed (Fig. 1 C, Fig.2 C). The smallest tributary (a) is $20.5 \mathrm{~km}$ long and $300 \mathrm{~m}$ average wide, with an ablation area of $6.3 \mathrm{~km}^{2}$; tributary (b) is 19.7 $\mathrm{km}$ long and $500 \mathrm{~m}$ wide, with an ablation area of $10.7 \mathrm{~km}^{2}$; tributary (c) is the longest one, which is $21.4 \mathrm{~km}$ long and $1500 \mathrm{~m}$ wide, with an ablation area of $30.1 \mathrm{~km}^{2}$. Surge occurred at tributaries (a), (b), and the confluence zone of three tributaries (Fig. 1 C). Longitudinal section of the major surging tributary (b) shows that the firn basin is $\sim 4 \mathrm{~km}$ long and $400 \mathrm{~m}$ high, having tongue section $\sim 8 \mathrm{~km}$ long with $400 \mathrm{~m}$ altitude difference, following the downstream trunk section $\sim 6 \mathrm{~km}$ long and dropped $300 \mathrm{~m}$ altitude(Fig. $2 \mathrm{~A}$ ). The upstreams of tributary (b) and (a) were convex which seem to be an ice reservoir, and the downstreams were concave which seem to be an ice receiving area (Fig. 2 A).

The superglacial moraine had well developed from trunk terminus upward to $10 \mathrm{~km} \mathrm{long}$, which is an important characteristic of the continental-type glacier. Its thickness gradually decrease from the downstream, average thickness of $\sim 0.3 \mathrm{~m}$ and maximum of $2-5 \mathrm{~m}$ (Fig. $3 \mathrm{P} 1$ ), to upstream. Glacial cliffs, about 10-300 m long and height difference of 5-40 m, were well developed in the midstream, at their feet often accompanied with superglacial lakes with diameter ranging from $10 \mathrm{~m}$ to $200 \mathrm{~m}$. The covered debris thickness in the upstream were less than $0.3 \mathrm{~m}$, and flow-textured crevasses were intensely developed. The height differences of glacier surfaces varied greatly and were up to $20 \mathrm{~m}$. The micro-morphological shapes were well-developed, and glacier fissures were interconnected, mainly characterized with englacial and subglacial ablations as well as subglacial rivers. These parameters indicate that it belongs to Tuomuer-type continental glacier (Mt. Tomor Glacier Research Team, CAS, 1982).

\section{Scenes of glacier surge}

On May 19, 2015, the glacier surge was investigated along the northwest Lateral Moraine Ridge (LMR) of tributary (a) (Fig. 1). The trunk section between terminus cliff and tributaries confluence was same as previous scenes (Fig. 3 P1), however the tributary (a) showed some amazing phenomena: the "black ice" fragmented expansion interbedded with debris in the glacier trough, which puncture through the overlying moraine layer to uplift 5-40 m high, and some parts were extruded out of the trough. The broken ice masses were pressed to override LMRs, forming "aground ice river". Hence, the debris-covered ice masses were directly irradiated and more largely faces exposed to air, which accelerated the ablation to form ice forests. The crests of some ice columns lifted the erratic moraine boulder, and the lower crevasses (mostly 1-10 m wide) were intersected vertically and horizontally. The melt water on ice block surfaces dripped down and flew around, making "rumbling" sound. Moreover, the ice forests and ice blocks collapsed continuously, together with moraine deposits and fell into crevasses. When they overflowed the LMR, the extruding-bulging ice masses collapsed and rolled down along the surfaces of LMR slope, and rapidly melted off, leaving a small moraine heap. Generally, the extruding-bulging scenes were most severe at the left mid-stream concave bank of tributary (a), and were gradually weakened towards up- and downstream (Fig. 2 B, D). To systematically and fully display this fractured extruding-bulging, we selected 5 typical scenarios from downstream to upstream (Fig. 3 P1 to P5), with corresponding positions and mirroring directions shown in Fig. 1C. 
The Cryosphere Discuss., doi:10.5194/tc-2015-235, 2016

Manuscript under review for journal The Cryosphere

Published: 29 February 2016

(c) Author(s) 2016. CC-BY 3.0 License.
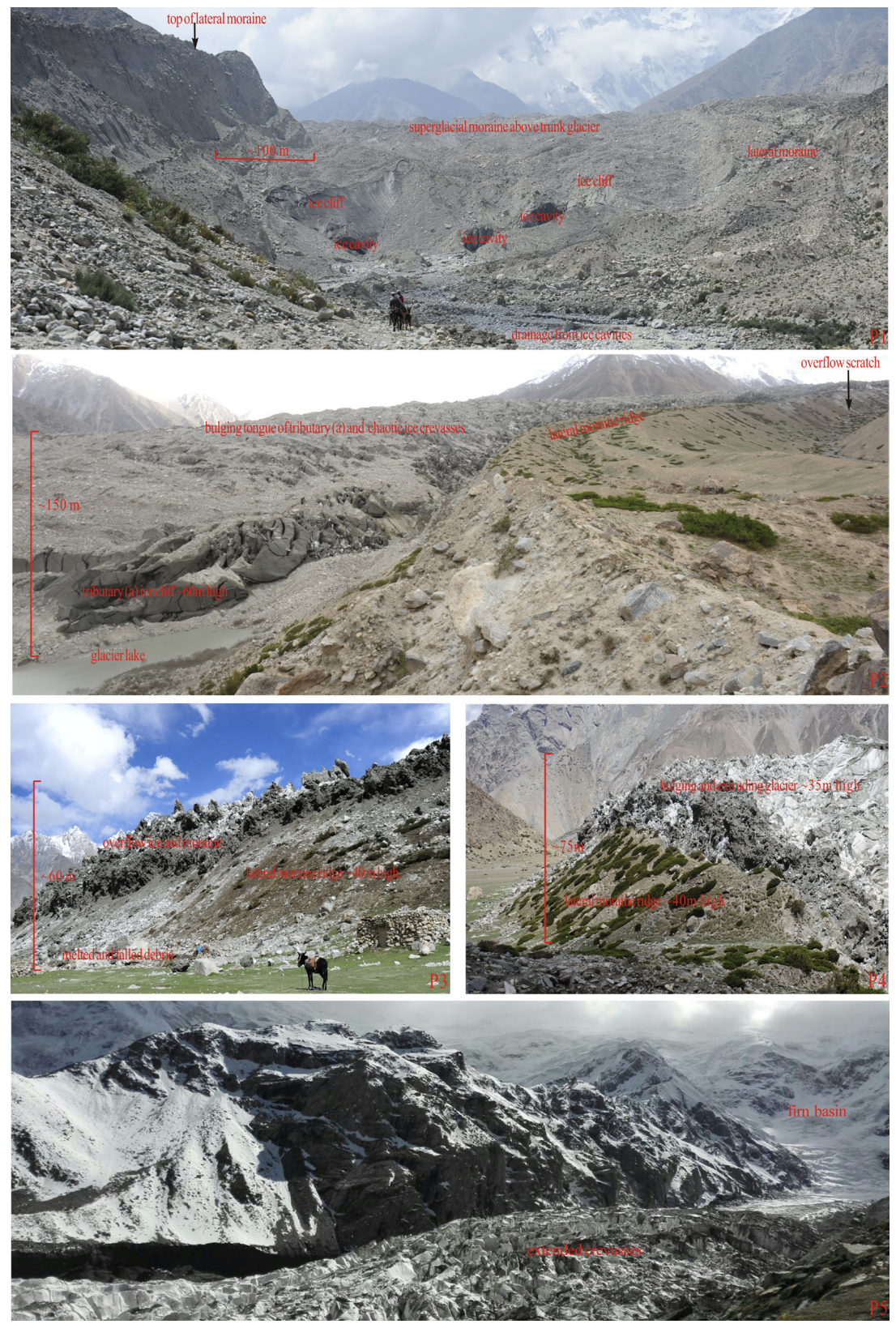

Fig. 3. Scenes of surge at Kelayayilake Glacier

P1 Undisturbed terminus of trunk glacier, 40-m-high and 200-m-wide glacial cliff, in which there were two 40-m-wide ice caves; water burst from the west one at a rate of $\sim 1-5 \mathrm{~m}^{3} / \mathrm{s}$, whereas no water from the east one. Surface covered $0.3-3 \mathrm{~m}$ thick debris, and occasionally found crevasses and ice wells; mirror direction $180^{\circ}$. $\mathbf{P 2}$ Terminus and downstream of tributary (a), ice mass extruded, uplifted, rushed through the overlying debris, formed chaotic crevasses, which directly reflected the causation of the disappearance of grasslands. The left-terminus of glacier (a) melted, forming 50-75 m high glacial cliffs and lakes. On the overall, mid-ridge uplifted above the lateral moraine ridge; mirror direction $145^{\circ}$. P3 Middle midstream of tributary (a), ice mass uplift and overflowing were most serious, and the extruded lower glacier masses fractured and expanded; black ice masses spilled out $\sim 10 \mathrm{~m}$ above the 45 -m-high lateral moraine ridge and were partially suspended outside the ice moraine ridge, starting to melt and fell down and endangering the grasslands and houses below it; mirror direction $61^{\circ}$. $\mathbf{P 4}$ Transverse section of upper midstream of tributary (a), glacier body expanded, fractured, wavy lifted, and extruded to overlap the $\sim 20$-m-high lateral moraine ridge. mirror direction $45^{\circ}$. P5 Source of glacier (a), ice mass flew out of the firn basin, mirror direction $250^{\circ}$. 
The Cryosphere Discuss., doi:10.5194/tc-2015-235, 2016

Manuscript under review for journal The Cryosphere

Published: 29 February 2016

(c) Author(s) 2016. CC-BY 3.0 License.

\section{Formation and development of surge}

Here in-situ investigation and multi-temporal RS images interpretation were carried out to determine the initiate time, process, deformation characteristics and velocity of glacier surge etc., which help us to understand Kelayayilake Glacier surge mechanism and evolution.

The RS data includes 8 periods of 15-m resolution ETM images, 3 periods of $2 \mathrm{~m} \mathrm{GF} 1$ images, and 1 period of $1 \mathrm{~m}$ QuickBird (QB) image. The data of glacier ablation is the qualitative observations of subglacial river water flow at trunk glacier terminus by local residents. On the other hand, the phenomena of glacier changes are the field observations. The time series of these data are listed in the axis of Fig. 4.

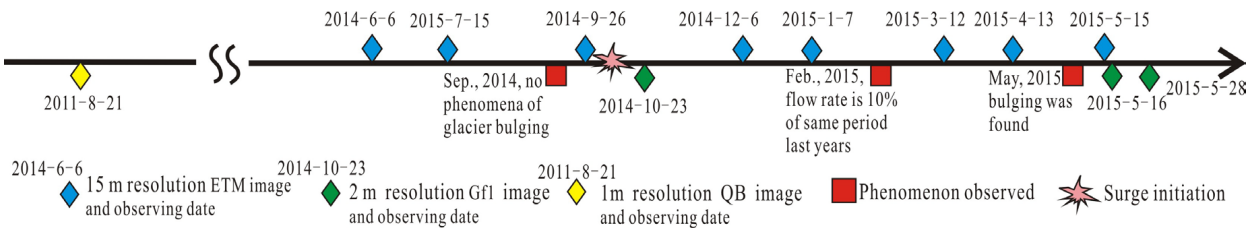

Fig. 4 Time series of observations for glacier surge

\subsection{Development process}

Glacier surge not only led color differences in surface debris, dirty ice, snow, superglacial lakes and crevasses, but also generated plasticity extruding \& bulging textures. Using multi-temporal observations (Fig. 5, Fig. 6, Fig. 7), we can divide the development process into five stages: inoculation $\rightarrow$ triggering $\rightarrow$ extrusion $\rightarrow$ surge $\rightarrow$ fracturing.

(1) Inoculation: 2011-8-21 QB and 2014-6-6 ETM revealed that the mid- and downstreams of both tributaries (a) and (b) were dominantly covered by moraine and only locally exposed ice showed the continuous flat textures, while tributary (c) was coarse-surfaced and covered throughout with glacial cliffs and superglacial lakes. The 2014-7-15 ETM image shows coarsened fluid textures in tributaries (a) and (b), but no obvious surface changes in tributary (c). These phenomena indicate that Kelayayilake Glacier had slow body movement and more stable surface morphology compared with oceanic glacier, but movement of tributaries (a) and (b) are relatively faster and unstable than that of tributary (c).

(2) Triggering: 2014-9-26 ETM and 2014-10-23 GF1 show that the "black ice" areas at midstreams of tributaries (a) and (b) were expanded and the scope of fluid coarse textures extended to the downstream, while the midstream moraine showed horizontally extrude-deformed textures, however the surface textures in tributary (c) were still coarsened, indicating the summer high temperatures led to the ablation of exposed ice masses and promoted the surge of tributaries (a) and (b). However, at this moment no ice bulging was observed at the LMR, because by the end of September, 2014 when the summer grazing ended, the herdsmen did not notice any glacier uplift when they departed from the neighborhood of this glacier.

(3) Extrusion. The 2014-12-06 and 2015-01-07 winter ETM images show that the exposed ice and superglacial lakes were frozen, and the low-lying places were covered by snow. The horizontal extruded textures at the midstreams of tributaries (a) and (b) became coarsened, likely the internal flow and extrusion stress strengthened significantly in the ice masses, preliminarily suggesting the surge blocked and extruded to uplift. Though covered by fresh snow, the 2015-03-12 ETM images show obvious extrusion with two evident characteristics: first, the textures of tributaries (a) and (b) were significantly darkened and started to horizontally expand, and the MMR was distorted in several positions; secondly, the front of the surge extruded textures reached the confluence with tributary (c) and got blocked, forming the extrusive uplift 
The Cryosphere Discuss., doi:10.5194/tc-2015-235, 2016

Manuscript under review for journal The Cryosphere

Published: 29 February 2016

(c) Author(s) 2016. CC-BY 3.0 License.

scarps, from which the surge scope could be outlined. At that time (Feb. 2015), the subglacial flow at the trunk terminus suffered a large reduction of about only $10 \%$ as that of previous years at the same time, and the flow was muddy, which indicated the alteration of subglacial water circulation.

(4) Surging. 2015-04-13 image shows that the extrusion of tributaries (a) and (b) propagated fast with significant lateral expansion, and the trajectory of MMR was further distorted. Tributary (a)'s left LMR was destroyed and became discontinuous. On the surface of three tributaries confluence zone and the downstream, the superglacial lakes displaced at a short distance, and extruding-bulging ice masses were melted at a large areas.

(5) Fracturing. 2015-05-15 ETM and 2015-5-16 GF1 showed the exposed ice masses were severely melting, fracturing and extruding. The mid- and downstreams of tributaries (a) and (b) were covered with "black ice", the arc-shaped horizontal compressed and short longitudinal tensional fissures were intersected vertically and horizontally, wavy distributed and spread on glacier surfaces. The ice masses were swollen, uplifted and "spilled out" of LMR. The melted ice clumps and moraines collapsed and rolled out of the LMR, forming the shoveled, melted and corroded scratch. The low-lying inner LMR was scraped and washed out the debris to the outer LMR (Fig. 2 D, Fig. 6 C-D), these scenes corresponds to Fig. 3 P2-4 as well. The MMR between tributaries (a) and (b) was further contorted, and some sections even disappeared. Notably, the tributary (c) at the confluence showed regular distribution and short extruded longitudinal tension crevasses, indicating this region had been the main anti-slip section and started to endure the major extrusion stress from the surge of tributaries (a) and (b).

Based on all evidences, we inferred that the low velocity glacier had been experiencing long-term stress and strain accumulation, and the surge initiated in Oct., 2014, grown in winter of 2014-2015, and fully broke out in the spring and summer of 2015.

\subsection{Surge velocity}

Unlike oceanic glaciers' evident rapid propulsion at the terminus, Kelayayilake Glacier surge was mainly characterized by extruding-bulging and uplift, hence the overall displacement was difficult to measure. We compared the position changes of featured points in mid- and downstreams of tributaries (a) and (b) to calculate the surge velocity, including the terminus (point $a$ in Fig. 6 A-D, Fig. 7), LMR (Fig. 6 A-D, pint $b$, c), extrusion fracture (Fig. 6 A-D, point $d$ ) and MMR (point $e, f$ in Fig. 6 E, F).

(1) The displacement from Aug. 21, 2011 to May 16, 2015 was 100 m, judged from relative positions between the terminus glacial cliff of tributary (a) (Fig. 6 B) and a meadow on the LMR. The MMR between the terminus of tributary (b) and tributary (c) moved $\sim 250 \mathrm{~m}$ downward (Fig. $6 \mathrm{C}, \mathrm{D}$ ), by the condition of gentle slope and blocking by tributary (c). From this, we deduced that at the mid- and upstreams was larger than $200 \mathrm{~m}$.

(2) From May 15 to 28, 2015, the surge front of tributaries (a) and (b) elongated $30 \mathrm{~m} \mathrm{(2.3} \mathrm{m/day),} \mathrm{about}$ 8 -fold as that of regular velocity, indicating the accelerated trend of development.

(3) Compared with 2014-10-23 (Fig. 6 E) and 2015-5-28 (Fig. 6 F) images, the MMR between tributaries (a) and (b) (point e in Fig. 6) shifted sideway up to $\sim 200 \mathrm{~m}$, and the point $f$ almost disappeared. Besides, ETM images on 2014-9-26 (Fig. 5 A) and 2015-5-15 (Fig. 5 F) show that the MMR at point $e$ moved laterally to a similar distance.

Thus, the advance distance estimated at the terminus of tributaries (a) and (b) was $\sim 200 \mathrm{~m}$. From October 2014 to May 2015, the average velocity was about $1.0 \mathrm{~m} /$ day. The displacement and the velocity of Kelayayilake Glacier is less as compared to those of oceanic glaciers (distance 1-11 km, velocity $0.15-6$ $\mathrm{km} /$ day); however, the propagation of fractured extruding-bulging was up to $33 \mathrm{~m} /$ day up- and downstreams 
The Cryosphere Discuss., doi:10.5194/tc-2015-235, 2016

Manuscript under review for journal The Cryosphere

Published: 29 February 2016

(c) Author(s) 2016. CC-BY 3.0 License.

\subsection{Volume}

For estimating glacier thickness and volume is uncertain, different types of methodologies were developed, the common used are Area-Volume, Slope-dependent, and Ice-thickness distribution (Frey et al., 2014; Haeberli et al., 2016). Subject to the available data, the Area-Volume were tended to use, for which there are also three sets of scaling parameters (Chen and Ohmura, 1990; Bahr et al., 1997; Su et al., 1984), which response to three volumes of $0.97,1.15$, and 1.32 billion $\mathrm{m}^{3}$ respectively for this glacier. Though the Su at al.(1984)'s is the largest, we are prone to use this one for three reasons: (1) The bigger volume seems to be more reliable, as the mean ice thicknesses are significantly higher in the Karakoram (94-158 m) than in the Himalayas (54-83 m) (Frey et al., 2014), and our study area is adjacent to Karakoram. (2) This set of parameters is deduced from the glaciers in Tian Shan which is similar to our study glacier, as well as all of them are continental type glaciers. (3) The parameters are the only available area-related parameters that exist for high Asian glaciers.

The surge area of tributaries (a) and (b) was about $13 \mathrm{~km}^{2}$. According to the statistical relationships between glacier area with its thickness and volume ( $\mathrm{Su}$ et al., 1984), estimated:

$$
\begin{aligned}
& H_{\mathrm{g}}=-11.23+53.21 A_{g}{ }^{0.3} \\
& V_{g}=0.0674 A_{g}{ }^{1.16}
\end{aligned}
$$

$A_{g}$ is the glacier area, the thickness $H_{g}=103.6 \mathrm{~m}$, and the volume $V_{g}=1.32$ billion $\mathrm{m}^{3}$.

In-situ expedition for tributaries (a) verify that the thicknesses are $\sim 32 \mathrm{~m}$ and $\sim 75 \mathrm{~m}$ at the banks of upstream and middle-stream, and $110 \mathrm{~m}$ at the terminus; the height of cliffs at trunk terminus was $\sim 40 \mathrm{~m}$. Commonly in case of U-shaped trough bottom, the thicknesses at the middle parts of cross sections should be larger and may be referred to the average thickness $(\sim 110 \mathrm{~m})$ of nearby similar continental glaciers in Tian Shan (Yang and An, 1991), the thicknesses and volumes of tributaries (a) and (b) estimated from equations 1-1 and 1-2 are acceptable.
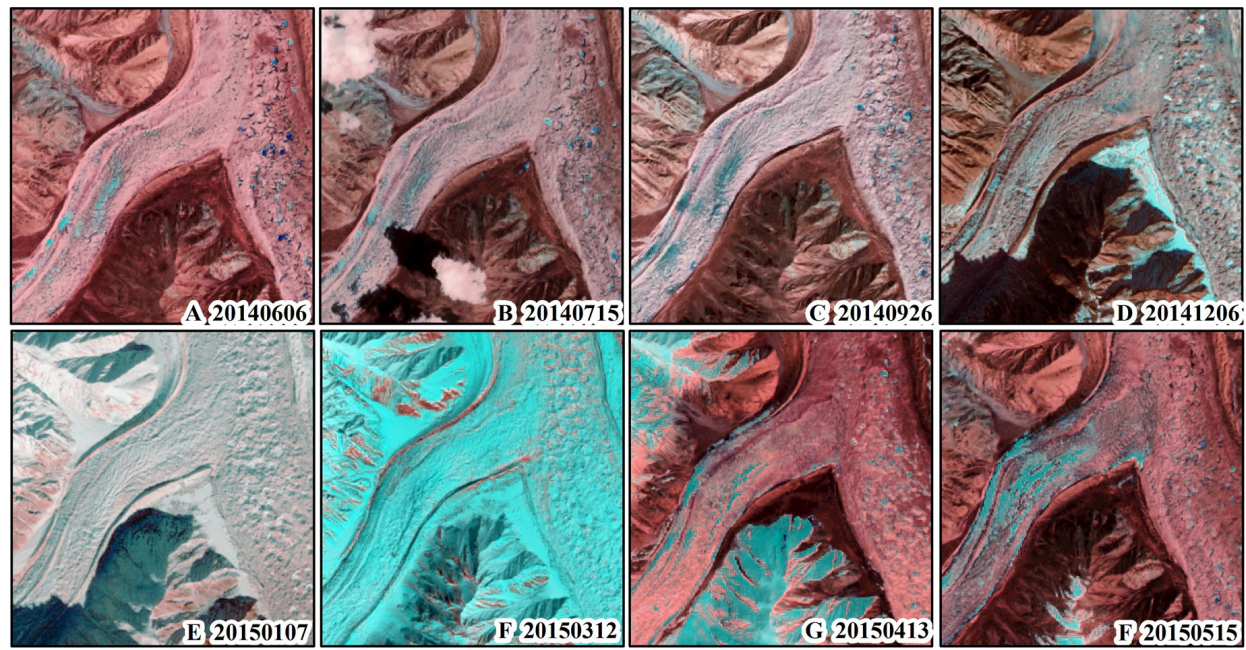

Fig. 5 Eight phase ETM RS images covering zone of mid- and downstreams of tributaries (a) and (b) 
The Cryosphere Discuss., doi:10.5194/tc-2015-235, 2016

Manuscript under review for journal The Cryosphere

Published: 29 February 2016

(c) Author(s) 2016. CC-BY 3.0 License.

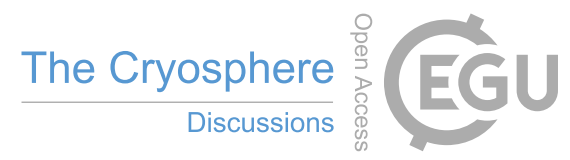
(c) (1)
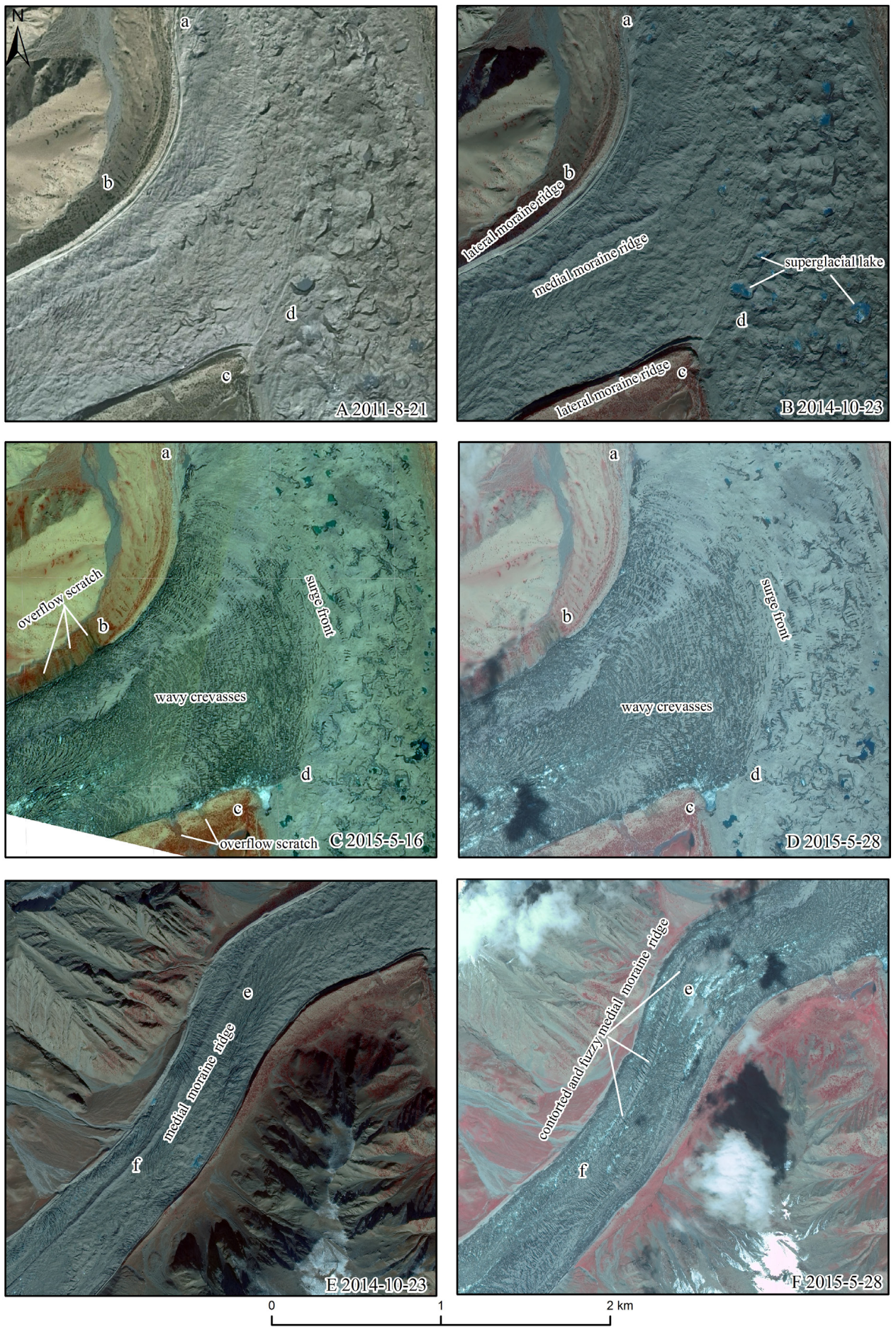

Fig. 6 Characteristics of glacier surge from high-resolution RS images 

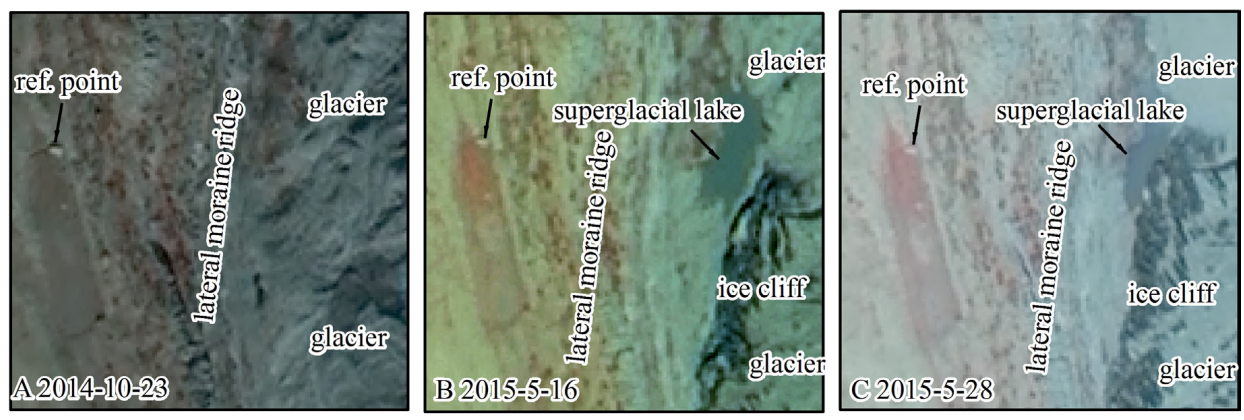

Fig. 7 Movements of glacial cliff and ice lakes at point $a$ in Fig. 6

\section{Analysis and discussion}

\subsection{Environmental factors}

Like any geo-phenomena, the occurrence of glacier surge depends on some environmental factors (relatively static state) as well as the triggering factors (relatively dynamic state).

The major environmental factors are stability coefficient (Yao, 1987) and geometrical shape (Clarke, 1991). Multivariate analysis indicates that surge-type glaciers are characteristically long, wide, and low-altitude tongue (Barrand and Murray, 1991). The critical glacier coefficient $(0.63), \sim 13 \mathrm{~km}^{2}$ tongue area and relatively lower tongue elevation ( $2780 \mathrm{~m}$ a.s.l. at terminus) of Kelayayilake Glacier are capable of inducing a surge. And tributary glaciers have a greater tendency to surge than trunk glaciers, presumably because they may themselves be surge-type and may additionally participate in surges of the trunk glacier (Clarke et al., 1986).

The velocities at firn basin and upstream were up to 100-1000 m/year, however the velocity at the trunk terminus was less than $10 \mathrm{~m}$ /year in previous years (Jiang et al., 2014). Together with the "steep upstream and gentle downstream" terrains, the moving glacier was blocked and extruded, forming a situation of "push from behind, block from front". As a result, the midstream and downstream ice masses fractured and uplifted which provided favorable conditions for the expansive ice masses to spill out of the trough and ultimately propagate to the upstream and the downstream. The downstream of tributary (a) is located on the concave bank side, where it became a main section of ice mass spillover.

In addition to this, thick moraine cover was another important factor for the special surging phenomena. Surface debris did not fully deposit from the surface ice ablation, and about 1/3-1/2 extruded from the englacial when the internal and bottom debris moved along the ice layers or fractured surfaces (Mt. Tomor Glacier Research Team, 1982; Shi et al., 1989), suggesting that the Kelayayilake Glacier has an active internal movement which contributes to stress accumulation.

Surface debris has a double effect on glaciers ablation. (1) Debris layer can significantly reduce surface reflectance and promote the absorption of radiant heat. When debris layer is thicker than 3-8 cm, it has a very small heat capacity and the moisture inside the thin-layer debris layer has high thermal conductivity, resulting in promotion of the ice surface ablation (Wang, 2011; Ding et al., 2014; Liu, et al., 2013); (2) on the other hand, when its thickness is very large, the downward conducted heat quantity was largely consumed by the surface gravels before entering the deep gravels or underlying ice surfaces, hence the surface debris inhibited the ice ablation and thus enhanced the glacier activity (Kang et al., 1985; Bookhagen and Strecker, 2011; Xie, et al., 2004; Han, et al., 2005).

As mentioned in section 2.3 of superglacial moraine characteristic, the ablation strength of tributaries (a) and (b) was highest in the lower midstream, and weakened upwards with the altitude rise and temperature reduction, and weakened downwards with the increase of debris thickness. The $\sim 0.3 \mathrm{~m}$ thick debris layer 
The Cryosphere Discuss., doi:10.5194/tc-2015-235, 2016

Manuscript under review for journal The Cryosphere

Published: 29 February 2016

(c) Author(s) 2016. CC-BY 3.0 License.

helped to preserve the glacier activity which was a key environmental condition that produced severe extruding-bulging at the mid- and downstreams, and was also the basis which make it different from oceanic glaciers.

\subsection{Triggering factors}

Two major types of triggering mechanisms for glacier surge initiated had been concluded (Robin, 1969). One is due to the temperature instability to promote basal glacier deformation and porosity, with a positive feedback among pore water pressure, deformation, and basal flow(Clarke et al., 1984; Murray et al., 2000), which is characterized by a relatively slow velocity and an initiation phase that lasts several years before the peak of the surge is reached and a termination phase that comprises several years of deceleration following the peak of the surge. These surges have been observed to begin their acceleration/deceleration independent on any seasonal control. (Murray et al., 2003). Another is due to subglacial pore water pressure instability, triggering the flow instability (Kamb et al., 1985; Björnsson, 1998). Such water pressure surges are characterized by rapid acceleration and deceleration (i.e., days to weeks long) (Kamb et al., 1985) and likely to initiate during winter season, when the drainage efficiency is low, and terminate during summer season, when the drainage efficiency is high (Burgess et al., 2012; Fatland and Lingle, 2003). Commonly, both type of surge were observed at oceanic glaciers, for the other type of surge, such as those at Karakoram region, they are heterogeneity of triggering mechanism (Quincey et al., 2015).

Though Gez active fault passes through glacier and induced big earthquake in the past, however no earthquakes of $\geq M \mathrm{~s} 4.0$ ever occurred within the $100 \mathrm{~km}$ radius of the glacier, since June 1,2014 , and the maximum magnitude within $10 \mathrm{~km}$ from the glacier was $M \mathrm{~L} 1.3$ (Fig. 1). Compared with the regional historical seismicity level, this was a relatively weak seismic period, so the stress instability from the external could be excluded from our analysis.

From weather station about $10 \mathrm{~km}$ away from the glacier surge zone, $2770 \mathrm{~m}$ a. s. 1., at Gez river valley (Fig. 1), the daily average temperature was $1.56{ }^{\circ} \mathrm{C}$, about $0.65{ }^{\circ} \mathrm{C}$ warmer from previous year; the daily maximum and minimum temperatures were 5.91 and $-1.9{ }^{\circ} \mathrm{C}$ respectively, which are about 0.97 and $0.42{ }^{\circ} \mathrm{C}$ warmer than those of previous year. The accumulative precipitation during the surge occurring and development periods (from Sep. 1, 2014 to Apr. 28, 2015) was $33.9 \mathrm{~mm}$, which was about 2.3 times that of the same period last year. The precipitation from 20 rain stations within $200 \mathrm{~km}$ of study area during the period from last winter to Apr. 2015, was about 3 to 4 times larger than the normal levels (private communication from $\mathrm{Xu}$ Baiqing). Moreover, as glacier zones had an apparent vertical climate, the precipitation above the snow line in the glacier accumulative area increased more significantly (Shi and Zhang, 1978). The glaciers in Muztag Ata, adjacent to study area (50 km away), have a slight mass gain contrary to the global trend, but with locally spatial and temporal glacier variations during the last four decades (Holzer et al., 2015). And for the farther distance, the glacier surges had expanded and increased in central Pamir since 1990s (Copland et al., 2011). All of these phenomena contribute to the long-period increase of precipitation and temperature, while a short, local fluctuation in NE-Pamir. Clearly, both short-term and long-term precipitation and accumulation patterns were favorable for the occurrence controlled by thermal conditions. On the contrary, the characteristics of surging initiate season, acceleration and deceleration, as well as velocity deviated from the conclusions of controlled by hydrological conditions.

\subsection{Periodicity}

Glacier surge is periodical which is about 15 to 100 year, and generally 20-30 year for some oceanic glaciers (Meier and Post, 1969). However, no reports on the repetition of thick debris-covered continental glaciers have been found. No data from previous surges are available in study area. However, based on interviews from the old people in the local village, a sudden flood and debris flow was witnessed at the 
The Cryosphere Discuss., doi:10.5194/tc-2015-235, 2016

Manuscript under review for journal The Cryosphere

Published: 29 February 2016

(c) Author(s) 2016. CC-BY 3.0 License.

confluence site of Kelayayilake Glacier and Gaz River about 100 years ago. "At early June that year, the downstream at the glacier valley was interrupted, and at late June, a sudden huge flood \& debris flow (wave about $100 \mathrm{~m}$ high) occurred, carrying cattle-, goat- or yurt-like stones into Gez River. Numerous trees along the way were destroyed. The debris flow did not stop until about $70 \mathrm{~km}$ away." The floods $\&$ debris flows on the northeastern Pamir were usually caused by the burst of ice lakes. However, according to hydrological and topographic condition in Kelayayilake Glacier valley (Fig. 1), this glacier region did not like to harbor forming conditions for ice lakes, and it is more likely to be a sudden burst of surging fractured ice masses. If this were true, the surge periodicity of this glacier should be a centenary scale.

\subsection{Disaster risk}

Different from most reported surges discharge to the fjords or desolation valleys in the remote polar region and depopulate zone, Kelayayilake Glacier is located aside the Gez River valley alone where the China-Pakistan international road passes. There are lots of passengers and property, hence the disaster risk become the most focus question when the surge occurred.

The glacier surges usually underwent three phenomena: evident MMR folds, ice surface fracturing, and sudden advance at glacier terminus (Meier and Post, 1969), and they ended by three results: internal advance, no disturber to the terminus; tongue advance, would made disaster to downstream; the tributary surge dam will play a import role for the trunk surge (Kotlyakov et al, 2008). Until June 2015, except terminus tongue advance, all of other phenomena had occurred.

Before June 2015, the drainage from the subglacial river at trunk terminus had significantly reduced and became muddy compared with the same period of previous years; however the simultaneous ablation raised dramatically because of the abundant crevasses and missing moraine protection. Based on regular glacier aquifer yield, it was estimated that the englacial water storage has being increased. The surge also made the hydro passageway to disturbance, and led to ice cavities congestion. In NE-Pamir, summer usually start from early April and ends by middle October, so the glacier ablation would continue in the upcoming few months. All of these may be the harbors risks of flood burst as that of hundred years ago, which thereby leads to the development of secondary disasters, such as debris flow.

\section{Conclusions}

A close observation by expedition and multi-temporal RS image interpretation show that the continental-type Kalayayilake Glacier in the northeastern Pamir has a significant phenomena difference between quiescent and surging phase, including distorted medial moraine ridge, extruding-bulging ice masses, disappeared superglacial lakes etc. Compared with oceanic glacier surge, its characteristics are relatively higher ice choking uplift, large chaotic crevasses interval area extent and centennial-scale repetition, but having small integral movement distance with low velocity. Environmental factors of large glacier coefficient, long tongue, low altitude, especially the stagnant downstream tongue and thick superglacial moraine, contribute to its features. And the long-term temperature rise and rainfall enhancement in NE-Pamir seem to be consistent with the occurrence of this surge. This surge brings out severe strength reduction of glacier, rapid ablation of ice, congestion in the subglacial passageway, and accumulation of englacial water, which have being bred the risk of terminus advance suddenly to result in flooding and debris flow. 
The Cryosphere Discuss., doi:10.5194/tc-2015-235, 2016

Manuscript under review for journal The Cryosphere

Published: 29 February 2016

(c) Author(s) 2016. CC-BY 3.0 License.

\section{Acknowledgements}

This research is supported by the China Geological Survey (12120114001401) and National Natural Science Foundation of China (40902059). Special thanks to Prof. Hou Chuntang and Prof. Zhao Zhizhong for their valuable suggestions for completing this research works. We will give thanks to Prof. Xu Baiqing for providing the information of temperature and rainfall. And we are thankful to handling editor Tobias Bolch, editor Anna Feist-Polner and anonymous reviewers for their constructive comments which greatly helped to improve the original manuscript and giving the opportunity to extended the revision time.

\section{Reference}

[1] Bahr, D. B., Meier, M. F., and Peckham, S. D.: The physical basis of glacier volume-area scaling, J. Geophys. Res.-Solid, 102, 20355-20362, 1997.

[2] Barrand, N. E. , and Murray, T.: Multivariate controls on the incidence of glacier surging in the Karakoram Himalaya Arctic, antarctic and alpine research 1991 38(4), 489-498, 1991.

[3] Björnsson, H.: Hydrological characteristics of the drainage system beneath a surging glacier, Nature, 395, 771-774, 1998.

[4] Burgess, E.W., Forster R. R., Larsen C. F., and Braun M.: Surge dynamics on Bering Glacier, Alaska, in 2008-2011,The Cryosphere, 6, 1251-1262, 2012.

[5] Chen, J. and Ohmura, A.: Estimation of Alpine glacier water resources and their change since the 1870s, IAHS Publications -Hydrology in Mountainous Regions, I - Hydrological Measurements; the water cycle, Proceedings of two Lausanne Symposia, August 1990, edited by: Lang, H. and Musy, A., IAHS Publ.,193, 127-135, 1990.

[6] Clarke, G. K. C., Collins S. G., and Thompson D. E.: Flow, thermal structure, and subglacial conditions of a surge-type glacier, Can. J. Earth Sci., 21(2), 232-240, 1984.

[7] Clarke G.K. C., Schmok J. P., Ommanney C. S. L., and Collins S. G.: Characteristics of surge-type glaciers. Journal of Geophysical Research, 91(B7), 7165-7180, 1986.

[8] Clarke G K C.: Length, width and slope influences on glacier surging, Journal of Glaciology, 37(126), 236-246, 1991.

[9] Copland L., Sylvestre T., Bishop M. P., Shroder J. F., Seong Y. B., Owen L. A., Bush A. and Kamp U.: Expanded and recently increased glacier surging in the Karakoram, Arctic, Antarctic, and Alpine Research, 43(4), 503-516, 2011.

[10] Ding G. X., Chen C. P., and Xie C. W.: Study of the ice tongue ablation features of a large glacier in the south slopes of the Mt. Tuomuer in the Tianshan Mountains, Journal of Glaciology and Geocryology, 36(1), 20-29, 2014.

[11] Fatland, D. R., and Lingle C. S.: Analysis of the 1993-95 Bering Glacier (Alaska) surge using differential SAR interferometry, J. Glaciol., 44(148), 532-546, 1998.

[12] Frappe, T. P., Clarke G. K. C.: Slow surge of Trapridge glacier, Yukon Territory, Canada, J. Geophys. Res., 112, F03S32, doi:10.1029/2006JF000607, 2007.

[13] Frey, H., Machguth, H., Huss, M., Huggel, C., Bajracharya, S., Bolch, T., Kulkarni, A., Linsbauer, A., Salzmann, N., and Stoffel, M.: Estimating the volume of glaciers in the Himalayan-Karakoram region using different methods, The Cryosphere, 8, 2313-2333, doi:10.5194/tc-8-2313-2014, 2014.

[14] Guo W. Q., Liu S. Y., and Xu J. L.: Monitoring recent surging of the Yulinchuan glacier on north slopes of Muztag Range by remote sensing, Journal of Glaciology and Geocryology, 34(4), 765-774, 2012.

[15] Haeberli, W.: Brief communication: On area- and slope-related thickness estimates and volume 
The Cryosphere Discuss., doi:10.5194/tc-2015-235, 2016

Manuscript under review for journal The Cryosphere

Published: 29 February 2016

(c) Author(s) 2016. CC-BY 3.0 License.

calculations for unmeasured glaciers, The Cryosphere Discuss., doi:10.5194/tc-2015-222, in review, 2016.

[16] Han H. D., Ding Y. J., and Liu S. Y.: Estimation and analysis of heat balance parameters in the ablation season of debris-covered Kerqikaer glacier, Tianshan Mountains, Journal of Glaciology and Geocryology, 27(1), 88-94, 2005.

[17] Holzer, N., Vijay, S., Yao, T., Xu, B., Buchroithner, M., and Bolch, T.: Four decades of glacier variations at Muztagh Ata (eastern Pamir): a multi-sensor study including Hexagon KH-9 and Pléiades data, The Cryosphere, 9, 2071-2088, doi:10.5194/tc-9-2071-2015, 2015.

[18] Jiang Z. L., Ding Y. J., and Liu S. Y.: A Study of the Debris-covered Glacier Limit Based on SAR, Advances in Earth Sciences, 27(11), 1245-1251, 2012.

[19] Jiang Z. L., Liu S. Y., and Long S. C.: Analysis of the glacier dynamics features in Kongur Mountain based on SAR technology and DEMs, Journal of Glaciology and Geocryology, 36(2), 286-295, 2014.

[20] Jónsson S. A., Schomacker A., Benediktsson Í. Ö., IngólfssonÓ., and Johnson M. D.: The drumlin field and the geomorphology of the Múlajökull surge-type glacier, central Iceland, Geomorphology 207, 213-220, 2014.

[21] Kamb B., Raymond C. F., and Harrison W. D.: Engelhardt Hermann, Echelmeyer K. A., Humphrey N., Brugman M. M., Pfeffer T.: Glacier surge mechanism: 1982-1983 Surge of Variegated Glacier., Science, 227 (4686), 469-479, 1985.

[22] Kang E. S., Zhu S. S., and Huang M. M.: Glaciers and weather in Mt. Tomor of Tianshan Mountains, Xinjiang People's Publishing House, Urumchi, 99-119, 1985.

[23] Kotlyakov V.M., Osipova G.B., and Tsvetkov, D.G.: Monitoring surging glaciers of the Pamirs, central Asia, from space, Annals of Glaciology, 48, 125-134, 2008.

[24] Li S. S., Zhang M.J., and Li Z.Q.: Variation of glacier terminuses in the Tianshan Mountains, China, during the Period of 1960-2009, Arid Zone Research, 30(2), 378-384, 2013.

[25] Liu W. G., Xiao C. D., and Liu J. S.: Analyzing the ablation rate characteristics of the Rongbuk glacier on the Mt. Qomolangma, central Himalayas, Journal of Glaciology and Geocryology, 35 (4), 814-823, 2013.

[26] Liu J. S., and Wang D.: Surging glacier found in upstream Yarkant River of Karakorum Mountains in 2009 summer, Journal of Glaciology and Geocryology, 31(5), 45, 2009.

[27] Mao W. Y., Sun B.G., and Wang T.: Change trends of temperature, precipitation and runoff Volume in the Kaxgar river basin since recent 50 years, Arid Zone Research, 23(4), 531-538, 2006.

[28] Meier M. F. and Post A. S.: What are glacier surges?, Canadian Journal of Earth Science, 1969, 6(4), 807-817, 1969.

[29] Mt. Tomor Glacier Research Team of Lanzhou Institute of Glaciology and Cryopedology, Chinese Academy of Sciences: Basic characteristics of glaciers in Mt. Tomor of Tianshan Mountains, Science in China, Ser. B, 12 (8), 736-744, 1982.

[30] Murray T., Strozzi T., Luckman A., and Jiskoot H.: Christakos P.: Is there a single surge mechanism? contrasts in dynamics between glacier surges in Svalbard and other regions, J. Geophys. Res., 108(B5), 2237, doi:10.1029/2002JB001906, 2003.

[31] Murray, T., G. W., Miller P. J., Woodward J., Smith A. M., Porter P. R., and Jiskoot H.: Glacier surge propagation by thermal evolution at the bed, J. Geophys. Res., 105(B6), 13,491-13,507, doi:10.1029/2000JB900066, 2000.

[32] Niu J. F., Liu J. S., and Wang D.: Monitoring on ice-dammed lake and related Surging Glaciers in Yarkant River, Karakorum in 2009, Journal of Mountain Science, 29(3), 276-282, 2011.

[33] Quincey, D. J., Glasser N. F., Cook S. J., and Luckman A.: Heterogeneity in Karakoram glacier surges, 
The Cryosphere Discuss., doi:10.5194/tc-2015-235, 2016

Manuscript under review for journal The Cryosphere

Published: 29 February 2016

(c) Author(s) 2016. CC-BY 3.0 License.

J. Geophys. Res. Earth Surf., 120, 1288-1300, doi:10.1002/2015JF003515, 2015.

[34] Quincey, D. J., Braun M., Glasser N. F., Bishop M. P., Hewitt K., and Luckman A.: Karakoram glacier surge dynamics, Geophys. Res. Lett., 38, L18504, doi:10.1029/2011GL049004, 2011.

[35] Robinson A. C., Yin A., Manning C. E., Harrison T. M., Zhang S. H., and Wang X. F.: Tectonic evolution of the northeastern Pamir: Constraints from the northern portion of the Cenozoic Kongur Shan extensional system, western China, Geological Society of America Bulletin,116 (7), 953-973, doi: 10.1130/B25375.1, 2006.

[36] Robin G. Q.: Initiation of glacier surges, Canadian Journal of Earth Sciences, 6(4): 919-928, 10.1139/e69-096, 1969.

[37] Scherler D., Bookhagen D. B, and Strecker M R.: Spatially variable response of Himalayan glaciers to climate change affected by debris cover. Nature Geoscience, , 4, 156-159, 2011.

[38] Shangguan D. H., Liu S. Y., and Ding Y. J.: Surging glacier found in Shaksgam River, Karakorum Mountains, Journal of Glaciology and Geocryology, 27(5), 641-64, 2005.

[39] Shi Y. F. and Zhang X. S.: Modern-time regression and progression of Batura glacier in Karakorum Mountains, Acta Geographica Sinica, 33(1), 27-40, 1978.

[40] Shi Y.F., Cui Z. J., and Li J. J.: Quarternary glaciers and environmental problems in east China, Science Press, Beijing, 1989.

[41] Shi Y. F.: Glaciers and environment in China: past, present and future, Science Press, Beijing, 2000.

[42] Shi Y. F., Cui Z. J. and Su Z.: Quarternary glaciers and environmental change in China, Hebei Science \& Technology Press, Shijiazhuang, 2006.

[43] Su, Z., Ding, L., and Liu, C. C.: Glacier thickness and its reserves calculation on Tianshan Mountains, Xinjiang Geogr., 7, 37-44, 1984.

[44] Su Z., Li S. and Wang Z. C.: Modern glaciers in Muztag and Kongur. Journal of Natural Resources, 4(3), 241-246, 1989.

[45] Wang L., Li Z. Q., and Wang F. T.: Spatial distribution of the debris layer on glaciers of the Tuomuer Peak, western Tian Shan, Journal of Earth Science, 22(4), 528-538, 2011.

[46] Xie C. W., Ding Y. J., and Liu S. Y.: Analysis on the glacial hydrological features of the glaciers on the south slope of Mt. Tuomuer and the effects on runoff, Arid Land Geography, 27(4), 570-575, 2004.

[47] Xue Y., Han P., and Feng G. H.: Change trend of the precipitation and air temperature in Xinjiang since recent half century, Arid Zone Research, 20(2), 127-130, 2003.

[48] Yang H. A., and An R. Z.: Resources and distribution of modern glaciers in Yarkant River watershed, Chinese glacier catalog (Tarim River inland watershed: Yarkant River watershed), volume 3, Science Press, Beijing, 3-5, 1991.

[49] Yao T. D.: Relations among glacier mass balance, snow line and climate - a case study in Glacier No.1 at the headwaters of Urumqi River, Tianshan Mountains, Journal of Glaciology and Geocryology, 9(4), 289-300, 1987.

[50] Yao T. D., Liu S. Y., and Pu J. C.: Recent glacial retreat in high Asia and its impact on water resource in Northwest China, Science in China, Ser. D, 34(6), 535-543, 2004.

[51] Zhang W. J.: A surging glacier in the Najiabawa Peak area, Journal of Glaciology and Geocryology, 5(4), 75-76, 1983. 